\title{
Effects of different rootstocks on the morphologic parameters of watermelon grafts during transplant production
}

\author{
Horváth, D. E., Takácsné Hájos, M. \\ Debrecen University AGTC MÉK, Institute of Horticulture
}

\begin{abstract}
Summary: Before Hungary joined the EU watermelon production was a key sector of the Hungarian vegetable industry. Its production area shrank by nearly $60 \%$ since 2004, it is only 5000 ha today. Stable and reliable market failed to evolve in the last years and extreme weather events occurred more frequently. An unfavourable growing season can notably affect the production volume of the next season.

Information gathered in the last years support the assumption, that suitable stocks can help eliminate the issues caused by extreme weather or short-term crop rotation. Choosing the right grafted or non-grafted transplant is not enough any more, growers also have to select stock. In fruit and vine production choosing the stock, which is the most suitable for the technology is evident and this approach should be widely adapted by watermelon growers as well.

In this research we investigated the growth parameters of different watermelon stocks and their effect on the scion during the transplant production. Measurements were carried out on seven different stock-scion combinations of the scion 'Topgun $\mathrm{F}_{l}$ ' hybrid. Two of the stocks were interspecific (Cucurbita maxima $\times$ Cucurbita moschata) and five stocks were Lagenaria-type (Lagenaria siceraria) stocks. We made and recorded observations of the transplants' length $(\mathrm{cm})$, diameter of the stock and scion $(\mathrm{mm})$, number of leaves (piece), root length (cm), root mass $(\mathrm{g})$ and shoot mass $(\mathrm{g})$.

We concluded that early pricking out of transplants with interspecific stocks is successful due to their hardiness and vigorous growth. The effect of the 'Shintosa camelforce $\mathrm{F}_{1}$ ' interspecific stock was outstanding. Furthermore, the results confirmed the practical observation that the root system of interspecific stocks grow vertically more allowing them to take up water and nutrients from lower soil layers in poor sandy soils. From the Lagenaria group the root system of the 'DG-01 $\mathrm{F}_{l}$ ' was similar to the interspecific stocks'. It can be grown even in sandy soil, however other Lagenaria-type stocks are more suitable for production in hard soils with nutrient supply because of their compact root system. This study can serve as a basis for further research in the topic that can conduce to site- and technology-specific stock selection.
\end{abstract}

Keywords: grafted watermelon seedling, attribution of rootstocks

\section{Introduction and Overview}

Grafting of cucurbits had been well known in Asia since the 6th century and these days Japan and South-Korea still have a lead role in this field (OMBÓDI, 2005).

The application of grafted watermelon transplants were introduced in Hungary due to frequent dying out of stems by fall in temperature and unprofessional land use. Crop rotation is not to be taken strictly thanks to the robust root system of the squash stock which, besides resistance, allows a more effective nutrient uptake from the soil (RIMÓCZI, 2002).

The most commonly used interspecific stock for grafting comes from the crossing of Cucurbita maxima $\times$ Cucurbita moschata. In the case of Lagenaria-type it is Lagenaria siceraria, however Cucumis africanus and Cucurbita ficifolia are also commonly used as watermelon rootstocks in other parts of the world.

According to experimental results, besides having a favourable effect on the leaf area, grafting increases the number of fruits as well as the weight and sugar content of fruits. (PETROPOULOS, et al. 2012). Other studies also prove that grafting enhances both the length of shoots and the number of lateral vines resulting in an increased root mass as well. Furthermore, it has been found that increased yield does not have a detrimental effect on the quality of fruit, i.e. rind thickness and the dry matter content of fruit flesh (ALAN, et al., 2007). The latter statement however is true only if special nutrient demand of the grafted watermelon is taken into account and this way the amount of nitrogen is decreased to its third at least. Proper root mass production calls for larger amount of phosphorus rather in the beginning of the crop year, while higher doses of potassium and magnesium are necessary to reach sufficient fruit yield. Increased amount of nutrients have to be applied on the land, however, due to better nutrient uptake, this quantity is smaller when considering it per leaf area square metres (TÖMPE, 2012).

Nevertheless, grafting changes the ratio of male and female flowers by decreasing the number of males. Furthermore, it positively affects lycopene content in the fruit by increasing its value by up to $57 \%$ and allows rootstocks to build resistance to certain Fusarium species (MOHAMED, et al., 2012). 
Lagenaria-type stocks provide protection against various Phytophthora species, however, this does not apply for interspecific rootstocks (KOUSIK, et al., 2012). Salt tolerance capacity becomes more enhanced in Lagenaria-type species allowing the leaves to be less exposed to damage by such stress factors (YANG, et al., 2012).

Similar experiments demonstrated that despite increased salt concentration the growth of interspecific rootstocks was more intense than as it is of the Lagenaria types. Furthermore, an improved level of photosynthetic activity was observed per leaf area unit (Balliu, et al., 2012).

According to POFU et al. (2011), stock selection protects against soil-born pathogenic organisms as well as nematodes. Their experiments confirmed that Cucumis africanus and Cucumis myriocarpus stocks preserved their resistance to nematodes after grafting. Nevertheless, stock selection also increases fruit yield and sugar content of fruits (POFU, et al., 2012).

The number of vascular tissues varies in different types of rootstocks. While this fact does not influence the success of grafting, the more the number of the vascular tissues are, the more intense the growth (YETISIR and SARI, 2004).

Elongation is prevented by the application of higher concentration salt solution during transplant growing. This way transplants remain compact until the end of the growing period. (Balliu, et al., 2012).

The stem diameter of grafting components has to be taken into account when grafting in order to reach a proper healing and that the development of grafts is undisturbed after planting out (POFU, et al., 2012).

\section{Material and Methods}

The research was set up at the Derecske Horticultural Research Site of KITE Zrt where we examined the effects of seven different stocks on the scion ('Topgun $F_{l}$ '). Five of the stocks were Lagenaria siceraria ('Argentario $F_{1}$,'Emphasis $F_{1}$,'Macis $F_{1}$,'DG-01 $F_{1}$,'NUN $3001 \quad F_{1}$ ') and two were interspecific (Cucurbita maxima $\times$ Cucurbita moschata) ('Shintosa camelforce $F_{1}$,',Ferro $R Z F_{1}$ '). As shown in Figure 1, manual sowing took place on 22 May, using $40 \times 60 \mathrm{~cm}$ plastic trays. Fifty pieces of each rootstock were sown in five repetitions applying ten seeds at each repetition. Mechanical sowing of the scion took place on 18 March 2012 as shown in Figure 2. Earlier sowing is necessary due to slow scion growth. Rootstocks are sown manually in every case because the seeds were rather big. Pindstrup, a white-dark turf based mixture with clay granules, served as growing (fibre size: $0-20 \mathrm{~mm}$ and $10-30 \mathrm{~mm}$, $\mathrm{pH}: 5.5)$. Due to the fact that cell volume in trays after grafting is insufficient for the root system and there is a greater risk of transplanting, Lagenaria stocks were transplanted into $7 \times 7 \times 6 \mathrm{~cm}$ pots on 1 April 2012.

Media used in this case was also Pindstrup together with Trifender (Trichoderma asperellum) of $100 \mathrm{~g} / \mathrm{m}^{3}$ in order to prevent damping-off. Grafting was carried out along with another on 3 April 2012 as shown in Figure 3. Some of the grafts started to grow stocks after healing that were removed on 19 April 2012. 2-3 EC solution was applied for irrigation, a $0.1-0.15 \%$ solution to prevent longitudinal growth. We used Agroleaf power Hihg $P$ in the first half of the nursery period where the ratio of N:P:K was 12:52:5, while we applied Ferticare from 23 April 2012 where $\mathrm{N}: \mathrm{P}: \mathrm{K}$ ratio was $15: 30: 15$ also in a concentration of $0.1 \%$.

Pest control had to be applied three times. After grafting, on 3 April 2012 we applied watering with Trifender of $0.5 \%$ to prevent drilling-off. Spraying took place on 12 April 2012; we used Actara (agent: tiametoxam, 20 g/100 1) against aphids and Cuproxat (agent: tribasic copper sulphate of $0.2 \%$ ) to prevent drilling-off. We repeated the treatments with the same agents in the same doses on 23 April 2012. We measured the height and the diameter of rootstocks before grafting, while the length of grafts, the number of leaves and the diameter of the graft and the scion were examined both before grafting and after healing.

Complex analysis of various stock-scion combinations was carried out at the end of the nursery period for the following seven morphologic characteristics: length of transplants $(\mathrm{cm})$, diameter of rootstocks and scion $(\mathrm{mm})$, number of leaves (pieces), root length $(\mathrm{cm})$, root mass $(\mathrm{g})$ and shoot mass (g).

Statistical data received was processed by Microsoft Excel's Analysis ToolPak.

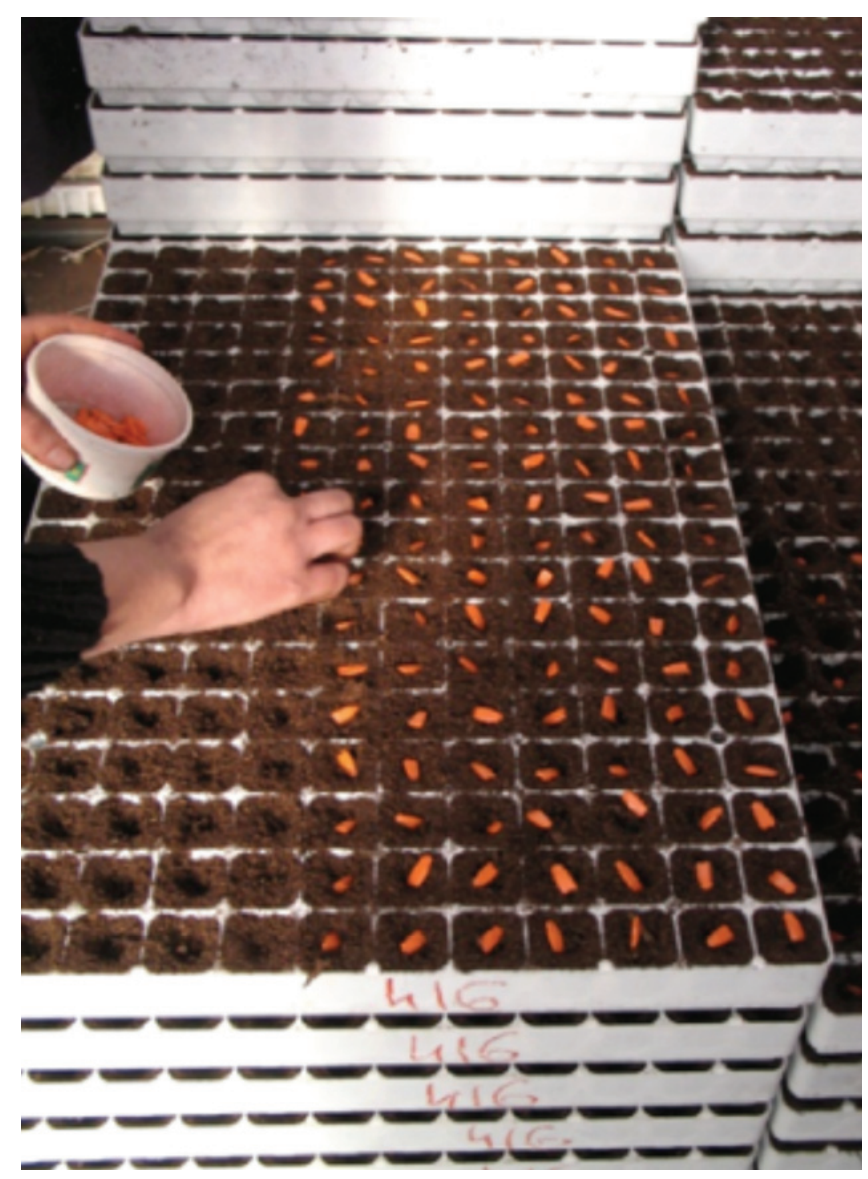

Figure 1: Manual sowing of rootstocks (Derecske, 2012) 


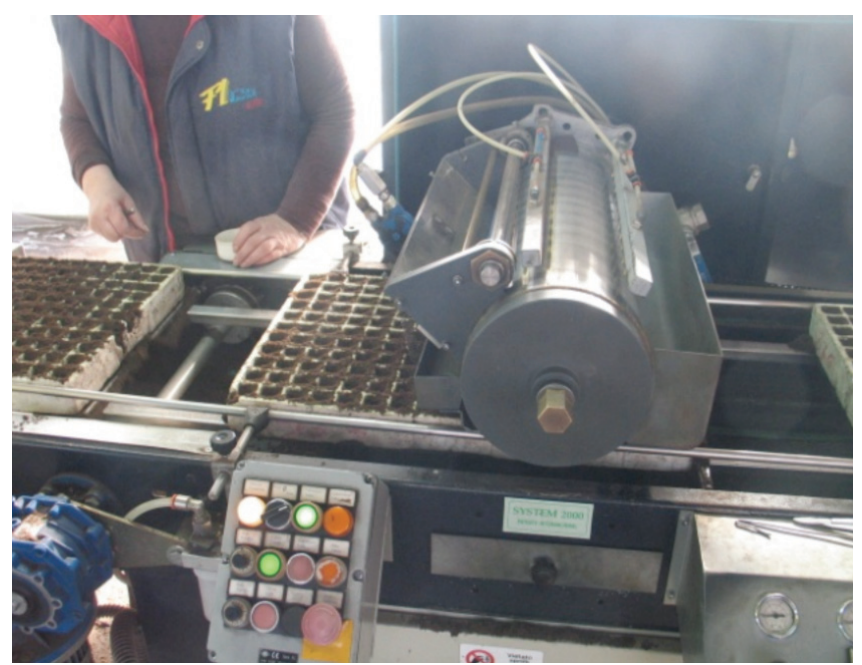

Figure 2: Mechanical sowing of scion (Derecske, 2012)

\section{Results and Evaluation}

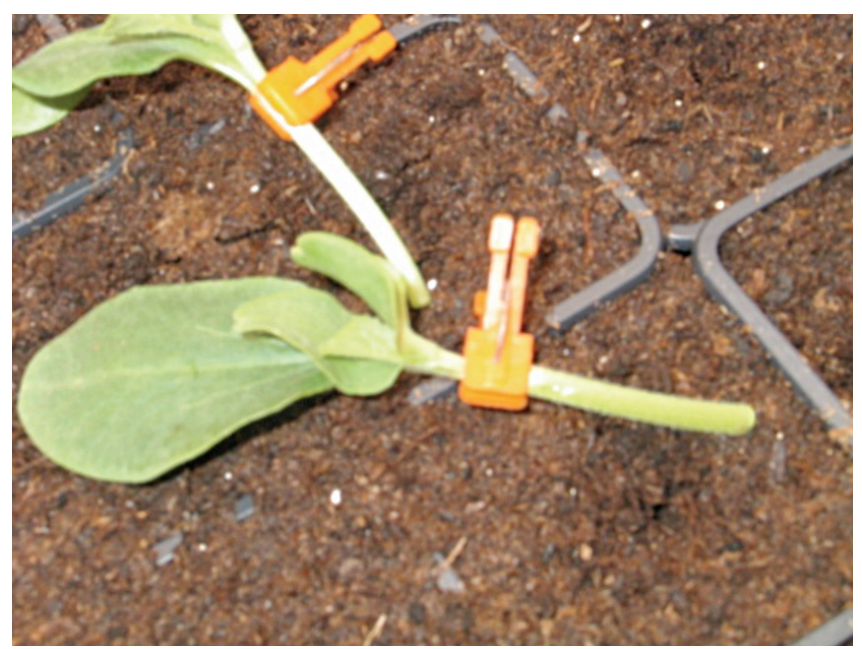

Figure 3: Grafting of interspecific rootstock (Derecske, 2012)

\section{Pre-grafting results}

Domestic analysis also supports the assumption that the intensity of growth of various types of rootstocks does vary. We experienced this difference as well since the plant height of interspecific stocks was significantly greater prior to grafting than as it is of the Lagenarias. Interspecific stocks had the

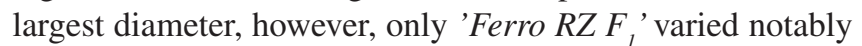
from the scion (Figure 4), although it did not have a negative effect on the success of the healing.

\section{Post-grafting results}

More intense growth of interspecific rootstocks was obvious in the initial growth period of grafts, however, by the end of the nursery period only 'Shintosa Camelforce $F_{j}$ ' preserved its greater height. Figure 5 demonstrates the total shoot growth.

Different types of stocks only slightly affected the thickness of scion, although we found significant differences as

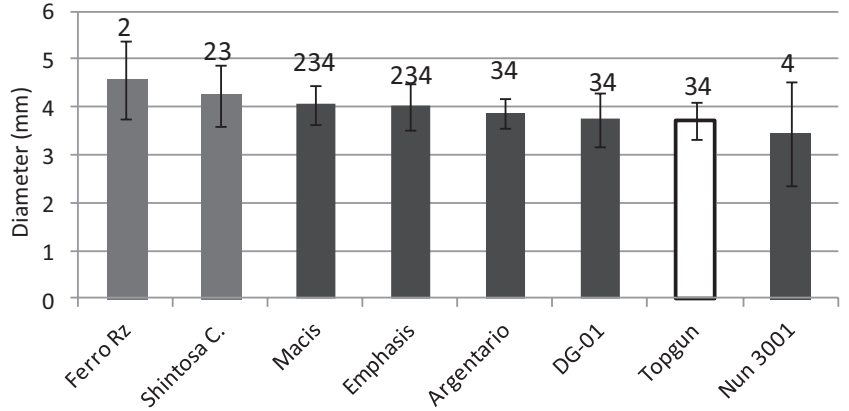

Figure 4: Diameter of grafting components (mm) prior to grafting (Derecske, 2012)

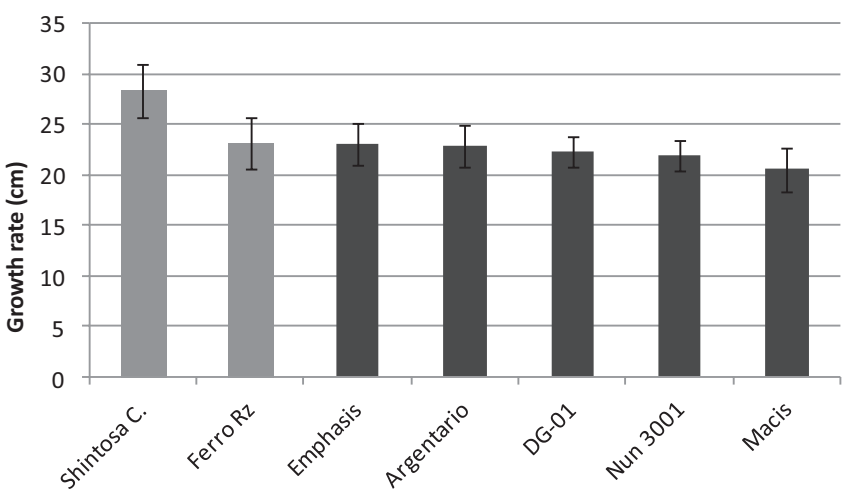

Figure 5: Total shoot growth (cm) (Derecske, 2012)

well. At the time of grafting, interspecific rootstocks had the largest diameter but the pace of thickening decreased during the nursery period and, in addition, these stocks had the smallest diameter by the end of the reference period.

We spotted differences between thicknesses of the examined Lagenaria-type stocks as shown in Figure 6 and these differences varied compared to the pre-grafting conditions. Diameters of 'Emphasis $F_{1}$ ', 'Macis $F_{1}$ ' and 'Argentario $F_{1}$ ' rootstocks were significantly (where $\mathbf{L S D}_{\mathbf{5 \%}}=0.488$ ) larger compared to other rootstocks.

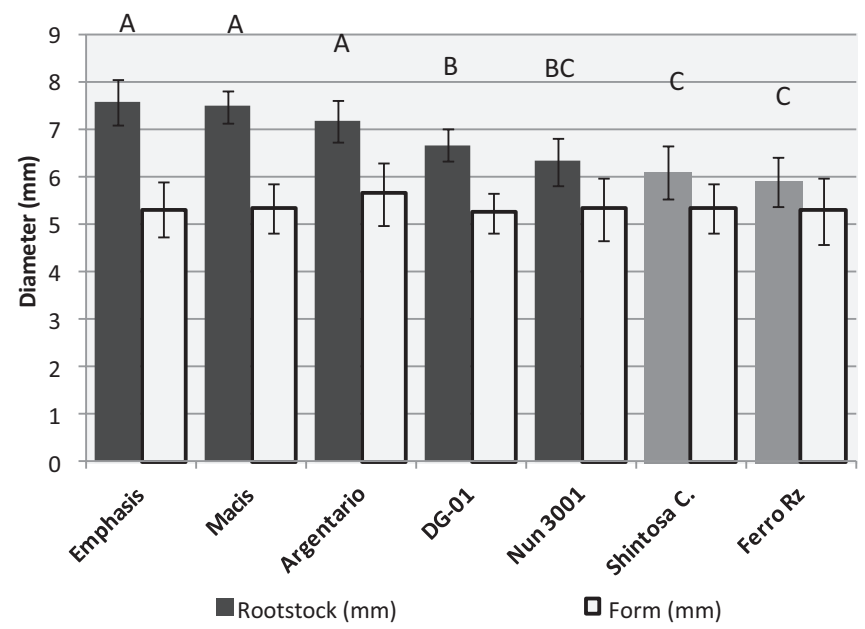

Figure 6: Stock and scion diameters before and after planting out (mm) (Derecske, 2012) 
Furthermore, we compared the ratio of stock and scion diameters with each other. We found differences amongst the various combinations however, as shown in Figure 7, this fact did not affect the viability of the graft.

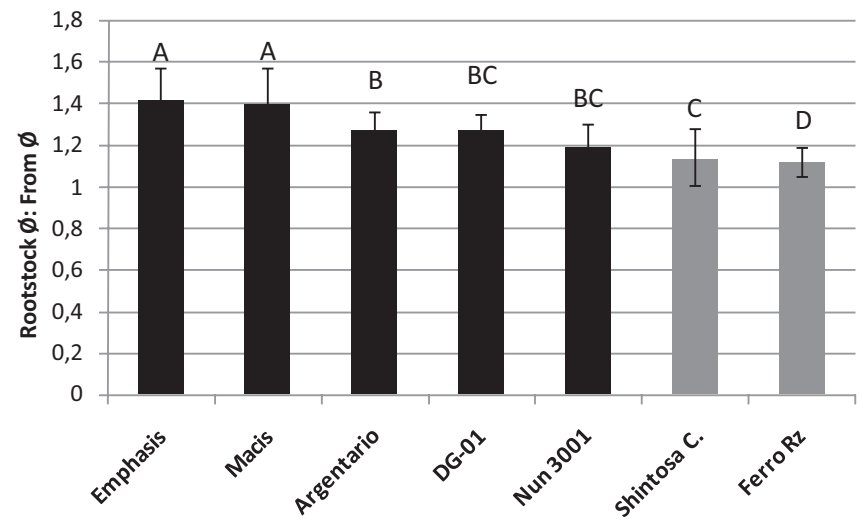

Figure 7: Rootstock - scion ratio of grafts (Derecske, 2012)

As shown in Figure 8, 'Argentario $F_{l}$ ' had the largest, while 'Ferro $R Z F_{1}$ ' the smallest root mass. In the case of other rootstocks, we found overlaps during the statistical analysis. As for root length we concluded that only 'Shintosa Camelforce $F_{1}$ ' had significantly longer root system.

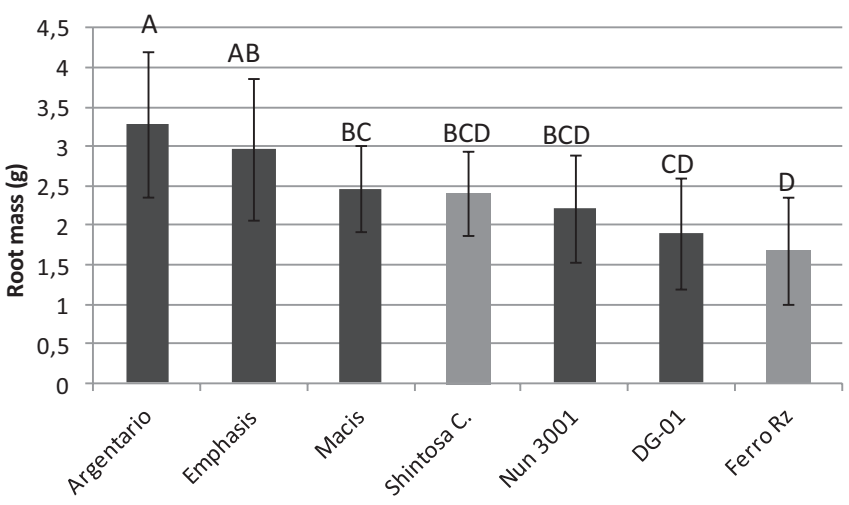

Figure 8: Roots mass of reference grafts (g) (Derecske, 2012)

We did not notice significant differences between root weights, however, compactness of root system does point differences between rootstocks out as pictured in Figure 9. This quality is the quotient of root length and mass leading to conclusion on root habit of certain rootstocks. It can clearly be established that rootstocks 'Ferro $R Z F_{1}$, , and 'Shintosa Camelforce $F_{1}$,' 'DG-01 $F_{1}$ ' root rather deep, while as for other rootstocks this feature is more compact (Figure 9).

It was interesting to experience that the root of Lagenariatype 'DG-01 $F_{1}$ ' was similar to interspecifics', i.e. its production might be suitable for poor quality soils, while positive characteristics of Lagenaria-types might also apply.

Further experience is that, within a certain type, the greater the root mass, the more compact it looks (Figure 8 and 9.).

We did not find significant difference between length and mass of shoots during the reference period which allows us

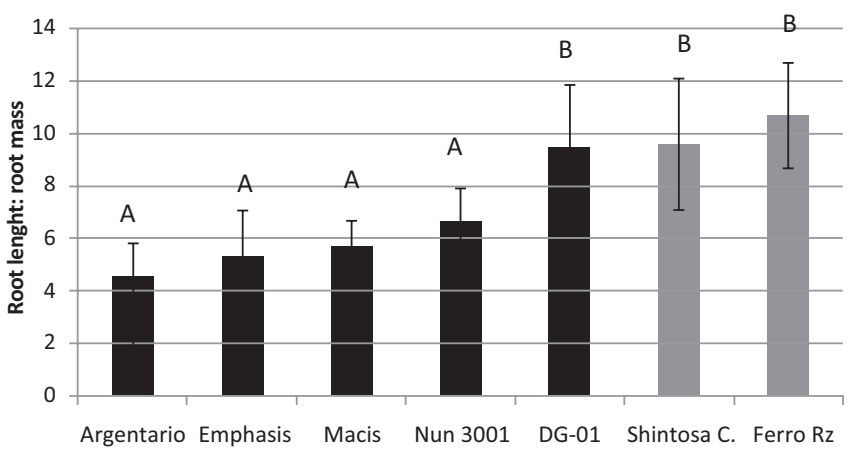

Figure 9: Ratio of root length (cm) and mass (g) (Derecske, 2012)

to state that the rootstock did not have any effect on these morphologic characteristics.

By monitoring the number of leaves during the experiment we concluded that there was no significant difference during the nursery period, i.e. in the case of transplants suitable for planting out there was no significant difference in the number of leaves amongst grafts.

\section{Acknowledgement}

We would like to thank the management and the employees of Derecske Horticultural Research Site of KITE Zrt for making it possible for us to do our research within operational conditions and also for their cooperation during the whole project.

\section{References}

Alan Ö., Özdemir, N., Günen, Y. (2007): Effect of grafting on watermelon plant growth, yield and quality, Journal of Agronomy 6 (2), pp. 362-365

Balliu, A., Sallaku, G., Babaj, I. (2012): The effect of watermelon (Citrullus aedulis) grafting methods on seedling's growth rate and plant stand establishment rate under saline conditions, Acta Horticulturae (Conference Paper )927 , pp. 393398

Kousik, C. S., Donahoo, R. S., Hassell, R. (2012): Resistance in watermelon rootstocks to crown rot caused by Phytophthora capsici, Crop Protection 39, pp. 18-25

Mohamed, F., El-Hamed, K., Elwan, M., Hussien, M.-A. (2012): Impact of grafting on watermelon growth, fruit yield and quality, Vegetable Crops Research Bulletin76 (1) , pp. 99-118

Ombódi, A. (2005): A dinnye oltásának története és elméleti alapjai. Hajtatás, Korai Termesztés. 36.4:9-12.

Petropoulos, S. A., Khah, E. M., Passam, H. C. (2012): Evaluation of rootstocks for watermelon grafting with reference to plant development, yield and fruit quality, International Journal of Plant Production 6 (4) , pp. 481-492

Pofu, K. M., Mashela, P. W., Mokgalong, N. M., Mphosi, M. S. (2011): Compatibility of watermelon (Citrullus lanatus) cultivars with nematode-resistant wild Cucumisseedling rootstocks, Acta Horticulturae ( Conference Paper ), 917, pp 253- 256

Pofu, K., Mashela, P., De Waele, D. (2012): Survival, flowering and productivity of watermelon (Citrullus lanatus) cultivars in intergeneric grafting on nematoderesistant Cucumis seedling rootstocks 
in Meloidogyne-infested fields, International Journal of Agriculture and Biology, 14 (2) , pp. 217-222

Rimóczi, I. (2002): Mire jó az oltás?. Kertészet és Szőlészet. 51.43:9-10

Tömpe, A. (2012): Kevesebb víz és tápanyag?. Kertészet és Szőlészet. 61.13:10.

Yang Y., Wang L., Jing T., Jing L., Jin V., Lizhong Ő., Shirong G., Takafumi T. (2012) : Proteomic study participating the enhancement of growth and salt tolerance of bottle gourd rootstockgrafted watermelon seedlings, Plant Physiology and Biochemistry58, pp. 54-65

Yetisir, H., Sari. N. (2004): Effect of hypocotyl morphology on survival rate and growth of watermelon seedlings grafted on rootstocks with different emergence performance at various temperatures, Turkish Journal of Agriculture and Forestry 28 (4), pp. 231-237 